Jurnal Kesmas Asclepius

Volume 2, Nomor 1, Juni 2020

e-ISSN: 2684-8287

p-ISSN: 2656-8926

DOI: https://doi.org/10.31539/jka.v2i1.1146

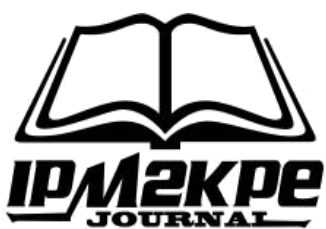

\title{
KUALITAS TIDUR BERHUBUNGAN DENGAN PERUBAHAN TEKANAN DARAH PADA LANSIA
}

\author{
Harsismanto $\mathbf{J}^{1}$, Juli Andri ${ }^{2}$, Tirta Dwi Payana ${ }^{3}$, \\ Muhammad Bagus Andrianto ${ }^{4}$, Andry Sartika ${ }^{5}$ \\ Universitas Muhammadiyah Bengkulu 1,2,3,4,5 \\ harsis@umb.ac.id ${ }^{1}$
}

\begin{abstract}
ABSTRAK
Tujuan penelitian ini adalah untuk mengetahui hubungan kualitas tidur dengan perubahan tekanan darah pada lansia hipertensi di Panti Sosial Tresna Werdha (PSTW) Provinsi Bengkulu. Jenis penelitian ini adalah penelitian kuantitatif berupa survey analitik dengan desain penelitian cross sectional. Hasil analisis univariat didapatkan tekanan darah pada lansia hipertensi di Panti Sosial Tresna Werdha (PSTW) yaitu 12 responden $(54,5 \%)$ mengalami hipertensi ringan, 10 responden $(45,5 \%)$ mengalami hipertensi sedang. Kualitas tidur yang dialami lansia hipertensi yaitu 11 responden (50\%) mengalami kualitas tidur yang baik dan 11 responden $(50 \%)$ lainnya mengalami kualitas tidur yang buruk. Hasil analisis bivariate menggunakan uji chi square didapatkan nilai $\rho$ value $=0,000$ dan nilai $\mathrm{C}=0,674$. Simpulan, ada hubungan yang signifikan dan kuat antara kualitas tidur dengan perubahan tekanan darah pada lansia hipertensi di Panti Sosial Tresna Werdha (PSTW) Tahun 2019. Kualitas tidur yang buruk berpengaruh pada perubahan tekanan darah lansia.
\end{abstract}

Kata Kunci: Kualitas Tidur, Lansia, Tekanan Darah

\section{ABSTRACT}

The purpose of this study was to determine the relationship of sleep quality with changes in blood pressure in elderly hypertension at Tresna Werdha Social Home (PSTW) Bengkulu Province. This type of research is quantitative research in the form of an analytic survey with a cross-sectional research design. Univariate analysis results showed blood pressure in hypertensive elderly at Tresna Werdha Social Home (PSTW), which is 12 respondents (54.5\%) had mild hypertension, ten respondents (45.5\%) had moderate hypertension. Sleep quality experienced by elderly hypertension, 11 respondents (50\%) experienced good sleep quality, and 11 other respondents (50\%) experienced poor sleep quality. The results of bivariate analysis using chi-square test obtained $\rho$ value $=0,000$ and $C$ value $=0.674$. In conclusion, there is a significant relationship between sleep quality and changes in blood pressure in hypertensive elderly at Tresna Werdha Social Home (PSTW) in 2019. Poor sleep quality affects changes in elderly blood pressure.

Keywords: Sleep Quality, Elderly, Blood Pressure 


\section{PENDAHULUAN}

Salah satu tujuan bangsa Indonesia yang tercantum dalam Nawacita ke lima yaitu peningkatan kualitas hidup manusia Indonesia (Kemenkes RI, 2015). Peningkatan kualitas hidup manusia Indonesia salah satunya dengan meningkatkan derajat Kesehatan dan kesejahteraan masyarakat berbagai kelompok usia yang merupakan salah satu investasi dan bentuk utama keberhasilan pembangunan kesehatan suatu bangsa. Dengan kualitas sumber daya manusia yang sehat dan sejahtera, pembangunan bangsa menjadi lebih cepat dan sesuai dengan harapan salah satu kelompok usia yang perlu dijaga kesehatannya adalah lansia (Primahadi, 2017).

BKKBN menjelaskan lansia (lanjut usia) merupakan seseorang dengan usia yang telah mencapai usia 60 tahun (Heri, 2019; Padila, 2013). Seperti halnya yang terjadi di negara-negara di dunia, Indonesia juga mengalami peningkatan jumlah penduduk lansia. Tahun 2019, jumlah lansia Indonesia diproyeksikan akan meningkat menjadi 27,5 juta atau 10,3\%, dan 57,0 juta jiwa atau 17,9\% pada tahun 2045 (BPS, 2018). Jumlah ini tidak sedikit, semakin banyak jumlah lansia apalagi lansia yang memerlukan bantuan kesehatan tentu akan memberikan kesulitan bagi keluarga, bahkan menghambat pembangunan bangsa, oleh sebab itu penting menjaga kesehatan dan kualitas hidup lansia.

Dengan tingginya angka kejadian hipertensi yang ada di Indonesia namun upaya untuk mengendalikan hipertensi tersebut masih kurang, perlu adanya berbagai macam upaya yang bisa dilakukan untuk mengendalikan angka kejadian hipertensi yang tinggi tersebut sehingga dapat menekan angka hipertensi (Andri et al., 2018; Sartika et al., 2018).

Peningkatan usia harapan hidup (UHH) lansia merupakan tanda keberhasilan pembangunan, terutama pembangunan kesehatan. Lansia merupakan salah satu kelompok atau populasi berisiko (population at risk) yang semakin meningkat jumlahnya. Dari segi aspek kesehatan, lansia menjadi kelompok yang rentan mengalami penurunan derajat kesehatan, baik secara alami maupun akibat proses penyakit. Penting untuk meningkatkan dan merencanakan berbagai program kesehatan yang ditujukan pada kelompok lansia (Kiik et al., 2018).

Dengan bertambahnya usia, fungsi fisiologis mengalami penurunan akibat proses degeneratif (penuaan). Proses menua pada manusia merupakan suatu peristiwa alamiah, menghilangnya kemampuan jaringan pada tubuh untuk memperbaiki diri dan mempertahankan fungsi tubuh sehingga terjadi penurunan daya tahan tubuh secara perlahan, akibatnya terjadi penurunan derajat kesehatan dan masalah kesehatan pada lansia secara progresif selain rentan mengalami penyakit menular lansia rentan mengalami penyakit tidak menular (Mubarak et al., 2015). Penyakit tidak menular pada lansia di antaranya hipertensi, stroke, diabetes mellitus dan radang sendi atau rematik dan asam urat. Sedangkan penyakit menular yang diderita adalah tuberkulosis, diare, pneumonia dan hepatitis (Riskesdas Kementerian Kesehatan RI, 2018). Salah satu penyakit yang banyak dialami oleh lansia yaitu penyakit system kardiovaskular, salah satunya adalah hipertensi (Ridwan et al., 2017).

Sudarso et al., (2019) menjelaskan kondisi penyakit kardiovaskular ini terjadi seiring pertambahan usia dimana terjadi penurunan elastisitas dinding pembuluh darah arteri dan kekakuan pada pembuluh darah sistemik akibat penuaan. Hal ini nantinya akan berhubungan kelainan pada sistem kardiovaskuler yang akan menyebabkan lansia rentan mengalami gangguan pada tekanan darah seperti hipertensi. 
Menurut Whelton et al., (2018) secara garis besar Hipertensi atau tekanan darah tinggi adalah peningkatan tekanan darah sistolik lebih dari $140 \mathrm{mmHg}$ dan tekanan darah diastolik lebih dari $90 \mathrm{mmHg}$ pada dua kali pengukuran dengan selang waktu lima menit dalam keadaan cukup istirahat/tenang, lebih lanjut, Kemenkes RI menjelaskan sampai saat ini, hipertensi merupakan penyakit yang memiliki prevalensi tinggi sebesar 25,8\% berdasarkan data Riskesdas tahun 2013 dan naik menjadi 34,1\% berdasarkan data Riskesdas tahun 2018 (Riskesdas Kementerian Kesehatan RI, 2013; 2018).

World Health Organization (WHO) tahun 2015 menunjukkan sekitar 1,13 Miliar orang di dunia menyandang hipertensi, artinya 1 dari 3 orang di dunia terdiagnosis hipertensi. Jumlah penyandang hipertensi terus meningkat setiap tahunnya, diperkirakan pada tahun 2025 akan ada 1,5 Miliar. Di Indonesia estimasi jumlah kasus hipertensi di Indonesia sebesar 63.309.620 orang, sedangkan angka kematian di Indonesia akibat hipertensi sebesar 427.218 kematian. Hipertensi terjadi pada kelompok umur 31-44 tahun $(31,6 \%)$, umur $45-54$ tahun $(45,3 \%)$, umur 55-64 tahun $(55,2 \%)$ (Riskesdas Kementerian Kesehatan RI, 2018).

Dari prevalensi hipertensi sebesar $34,1 \%$ diketahui bahwa sebesar $8,8 \%$ terdiagnosis hipertensi dan 13,3\% orang yang terdiagnosis hipertensi tidak minum obat serta $32,3 \%$ tidak rutin minum obat. Hal ini menunjukkan bahwa sebagian besar penderita hipertensi tidak mengetahui bahwa dirinya hipertensi sehingga tidak mendapatkan pengobatan. Berdasarkan data terlihat kelompok lansia usia 55-64 tahun memiliki prevalensi hipertensi tertinggi (P2PTM Kemenkes RI, 2019). Berdasarkan data dari Profil Kesehatan Provinsi Bengkulu Tahun 2018 estimasi penderita yang mengalami hipertensi di provinsi bengkulu sebanyak 889.010 dan hanya $9 \%$ yang mendapatkan pelayanan atau memanfaatkan pelayanan kesehatan sesusai standar (DINKES Provinsi Bengkulu, 2019).

Penyebab pasti hipertensi belum diketahui dengan pasti, namun ada beberapa faktor resiko yang menjadi pencetus terjadinya hipertensi, diantaranya adalah stress, kegemukan, merokok, asupan garam yang tinggi, sensitifitas terhadap angiotensin, hiperkolesteroemia, kurang olah raga, genetik, obesitas, ateroskllerosis, kelainan ginjal, gaya hidup dan kualitas tidur yang buruk (Pusat Data dan Informasi Kemenkes RI, 2014).

Beberapa penelitian menemukan hubungan beberapa faktor resiko penyebab dengan kejadian hipertensi pada lansia yaitu aktifitas fisik yang rendah meningkatkan resiko hipertensi pada lansia, asupan lemak dan natrium yang tinggi, merokok, kurang olahraga dan kualitas tidur lansia yang rendah (Amanda et al., 2016; Iswahyuni, 2017; Mahmudah et al., 2015).

Hipertensi sering di istilahkan dengan the silent killer karena sering tanpa keluhan, sehingga penderita tidak mengetahui dirinya menyandang hipertensi dan baru diketahui setelah terjadi komplikasi. Kerusakan organ target akibat komplikasi Hipertensi akan tergantung kepada besarnya peningkatan tekanan darah dan lamanya kondisi tekanan darah yang tidak terdiagnosis dan tidak diobati. Organ-organ tubuh yang menjadi target antara lain otak, mata, jantung, ginjal, dan dapat juga berakibat kepada pembuluh darah arteri perifer (P2PTM Kemenkes RI, 2019; Padila, 2012).

Hipertensi menjadi faktor resiko utama untuk terjadinya penyakit jantung, gagal jantung kongesif, stroke, gangguan penglihatan dan penyakit ginjal. Tekanan darah yang tinggi umumnya meningkatkan resiko terjadinya komplikasi tersebut. Hipertensi yang tidak di identifikasi secara dini dan tidak mendapakan pengobatan yang memadai 
akan mempengaruhi semua sistem organ dan akhirnya memperpendek harapan hidup sebesar 10-20 tahun (Nuraini, 2015).

Salah satu kondisi yang berkenaan dengan penuaan adalah masalah kualitas tidur, lebih dari setengah populasi lansia mengalami masalah dengan kualitas tidur (Andri et al., 2019). Kualitas tidur merupakan suatu kepuasan terhadap tidur yang dialami, Gejala-gejala dari masalah tidur pada lansia diantaranya adalah kesulitan tidur dan menjaga tidur, bangun dini hari dan rasa kantuk yang berlebihan di siang hari. Konsekuensi-konsekuensi dari permasalahan tidur yang kronis cukup besar. Kehilangan waktu tidur atau penggunaan obat penenang yang kronis yang dapat menyebabkan terjadinya jatuh atau kecelakaan. Gangguan pernapasan saat tidur bisa memberikan dampak yang serius pada kardiovaskular, paru-paru dan system syaraf pusat. Buktibukti mendukung adanya sebuah hubungan yang kuat antara sleep apnea dengan hipertensi (Ari et al., 2017).

Selama tidur terjadi penurunan tekanan darah relative selama terjaga, penurunan ini terjadi akibat penurunan kerja saraf simpatik terjadi berkisar 10-20\% dari tekanan darah normal, kualitas tidur yang buruk, seperti banyak terjaga, kesulitan memulai tidur, dan kurangnya kualitas tidur berpengaruh terhadap keseimbangan dan penurunan tekanan darah, pada kondisi kualitas tidur yang buruk, sering terjaga di malam hari, kurangnya waktu tidur bahkan akan meningkatkan tekanan darah. Beberapa penelitan sebelumnya menunjukan lansia cenderung lebih banyak mengalami gangguan tidur dan memiliki kualitas tidur yang buruk dengan sebagian besar dialami oleh perempuan, sebagian besar lansia insomnia, dan mengalami pola tidur yang buruk (Martini et al., 2018; Ernawati et al., 2017; Zulfitri et al., 2018).

Berdasarkan data yang diperoleh dari Panti Sosial Tresna Werdha (PSTW) pada tahun 2018 jumlah lansia yang mengalami hipertensi sebanyak 32 orang dari 60 lansia, pada tahun 2019 rata-rata kekambuhan hipertensi dari Januari sampai dengan Juni sebanyak 22 orang dari 87 lansia (Panti Sosial Tresna Werdha, 2018).

Survey awal yang peneliti lakukan pada 10 pasien lansia yang mengalami hipertensi di di Panti Sosial Tresna Werdha didapatkan informasi 7 orang lansia mengalami kesulitan memulai tidur, sering terbangun dimalam hari dan waktu tidur yang kurang, sedangkan pada 3 orang lansia hipertensi lainnya menyatakan bahwa mereka tidak mengalami masalah tidur. berdasarkan uraian diatas, peneliti merasa perlu meneliti lebih lanjut kaitan antara kualitas tidur dengan perubahan tekanan darah pada lansia dengan hipertensi, dengan tujuan untuk mengetahui hubungan antara kualitas tidur dengan perubahan tekanan darah pada lansia hipertensi di Panti Sosial Tresna Wherda (PSTW) provinsi Bengkulu.

\section{METODE PENELITIAN}

Penelitian ini merupakan penelitian kuantitatif dengan pendekatan survey analitik menggunakan desain penelitian cross sectional. Variabel independen dalam penelitian ini adalah kualitas Tidur, sedangkan variabel dependen adalah tekanan darah pada lansia hipertensi. Waktu penelitian dilakukan pada bulan Oktober 2019. Sampel dalam penelitian ini berjumlah 22 pasien lansia dengan hipertensi diambil dengan teknik total sampling.

Data yang dikumpulkan dalam penelitian ini yaitu data primer dan data sekunder, data primer berupa kualitas tidur lansia dengan hipertensi menggunakan kuesioner dan hasil pengukuran tekanan darah lansia sistolik dan diastolik menggunakan tensimeter. 
Data yang diperoleh diuji menggunakan uji chi square untuk melihat hubungan antara variabel independen dan variabel dependen.

\section{HASIL PENELITIAN \\ Analisis Univariat}

Tabel. 1

Distribusi Frekuensi Umur Lansia dengan Hipertensi

\begin{tabular}{cccc}
\hline No & Umur & $\begin{array}{c}\text { Frekuensi } \\
(\mathrm{f})\end{array}$ & $\begin{array}{c}\text { Persentase } \\
(\%)\end{array}$ \\
\hline 1 & $<65$ Tahun & 1 & 4,5 \\
2 & $\geq 65$ Tahun & 21 & 95,5 \\
\cline { 2 - 4 } & Total & 22 & 100,0 \\
\hline
\end{tabular}

Berdasarkan tabel 1 sebagian besar responden yaitu sebanyak 22 orang responden $(95,5 \%)$ lansia yang mengalami hipertensi berusia lebih dari 65 tahun.

Tabel. 2

Distribusi Frekuensi Tekanan Darah pada Lansia Hipertensi

\begin{tabular}{cccc}
\hline No & Tekanan Darah Lansia & $\begin{array}{c}\text { Frekuensi } \\
(\mathrm{f})\end{array}$ & $\begin{array}{c}\text { Persentase } \\
(\%)\end{array}$ \\
\hline 1 & Hipertensi Ringan & 12 & 54.5 \\
2 & Hipertensi Sedang & 10 & 45.5 \\
\hline & Total & 22 & 100,0 \\
\hline
\end{tabular}

Berdasarkan tabel 2 dapat diketahui bahwa sebagian besar responden mengalami hipertensi ringan yaitu berjumlah 12 orang responden $(54,5 \%)$.

Tabel. 3

Distribusi Frekuensi Kualitas Tidur yang Dialami Lansia Hipertensi

\begin{tabular}{cccc}
\hline No & Kualitas Tidur & $\begin{array}{c}\text { Frekuensi } \\
(\mathrm{f})\end{array}$ & $\begin{array}{c}\text { Persentase } \\
(\%)\end{array}$ \\
\hline 1 & Buruk & 11 & 50.0 \\
\hline 2 & Baik & 11 & 50.0 \\
\hline & Total & 22 & 100,00 \\
\hline
\end{tabular}

Berdasarkan tabel 3 di atas dapat diketahui bahwa kualitas tidur yang di alami lansia hipertensi di panti sosial tresna wherda (PSTW) yaitu 11 orang responden $(50 \%)$ mengalami kualitas tidur yang baik dan 11 orang responden $(50 \%)$ mengalami kualitas tidur yang buruk. 


\section{Analisa Bivariat}

Tabel. 4

Hubungan Pola Tidur dengan Perubahan Tekanan Darah pada Lansia Hipertensi

\begin{tabular}{|c|c|c|c|c|c|c|c|c|}
\hline \multirow[t]{4}{*}{ Pola Tidur } & \multicolumn{4}{|c|}{ Tekanan Darah } & \multicolumn{2}{|c|}{ Total } & \multirow{4}{*}{$\begin{array}{c}P \\
\text { Value }\end{array}$} & \multirow{4}{*}{$C$} \\
\hline & \multirow{2}{*}{\multicolumn{2}{|c|}{ Hipertensi Ringan }} & \multicolumn{2}{|c|}{ Hipertensi } & \multirow[b]{3}{*}{$\mathrm{F}$} & \multirow[b]{3}{*}{$\%$} & & \\
\hline & & & & & & & & \\
\hline & $\mathrm{F}$ & $\%$ & $\mathrm{~F}$ & $\%$ & & & & \\
\hline Baik & 11 & 50 & 0 & 0 & 11 & 50 & & \\
\hline Buruk & 1 & 4,5 & 10 & 45,5 & 11 & 50 & 0,000 & 0,674 \\
\hline Total & 12 & 54,5 & 10 & 45,5 & 22 & 100 & & \\
\hline
\end{tabular}

Berdasarkan tabel 4 diatas terlihat bahwa dari hasil uji continuity correction $^{b}$ didapatkan nilai $\rho$ value $=0,000<\alpha=0,05$. Hal ini menunjukan bahwa ada hubungan yang signifikan antara kualitas tidur dengan perubahan tekanan darah pada lansia hipertensi di Panti Sosial Tresna Werdha (PSTW) Tahun 2019. Hasil penelitian ini menunjukkan terdapat hubungan erat antara kualitas tidur dengan perubahan tekanan darah pada lansia hipertensi di Panti Sosial Tresna Werdha (PSTW) Tahun 2019.

\section{PEMBAHASAN}

\section{Analisis Univariat}

Berdasarkan data hasil penelitian diketahui bahwa umur responden penderita hipertensi di panti sosial tresna wherda (PSTW) tahun 2019 dari 22 orang responden 1 orang responden $(4,5 \%)$ berumur $<65$ tahun dan 21 orang responden $(95,5 \%)$ berumur $>65$ tahun. Peningkatan tekanan darah pada lansia di Panti Sosial Tresna Wherda (PSTW) provinsi Bengkulu mayoritas berada di usia >60 tahun, hal ini menunjukkan bahwa lansia memiliki prevalensi lebih besar mengalami resiko hipertensi. Penelitian Alfie \& Cuffaro (2019) menunjukkan lansia memiliki prevalensi terbesar terkena hipertensi. Hal ini juga sesuai dengan data dari hasil riskesdas yang mendapatkan data bahwa pada kelompok umur 55-64 tahun jumlah penderita hipertensi di Indonesia sebanyak 55,2\%, lebih tinggi dari kelompok usia lainnya (Riskesdas Kementerian Kesehatan RI, 2018).

Kerentanan lansia mengalami hipertensi dipengaruhi sendiri oleh proses penuaan yang terjadi secara alami pada lansia. Proses penuaan akan mengakibatkan perubahan fungsi baik fisik dan fisiologis tubuh, dalam hal ini perubahan fisik terjadi pada system kardiovaskuler dimana pembuluh darah lansia mulai mengalami kekakuan dan kehilangan elastisitas (Writes, 2017).

Berdasarkan data yang diperoleh pada penelitian ini, dari 22 responden lansia yang mengalami hipertensi didapatkan 12 orang lansia $(54,5 \%)$ mengalami hipertensi ringan (mild/grade 1) dengan tekanan darah sistolik 140-159 $\mathrm{mmHg}$ dan diastolic 90$99 \mathrm{mmHg}$ dan 10 orang lansia $(45,5 \%)$ mengalami hipertensi sedang atau berada pada rentang hipertensi sedang (moderate/grade 2). Rentang hipertensi ini berdasarkan panduan dari WHO dan international Society of Hypertension (ISH) tahun 1999 (Anandita et al., 2020).

Hasil penelitian ini sejalan dengan penelitian yang dilakukan oleh Zulfitri et al., (2018) yang menyatakan sebagian besar lansia yang mengalami hipertensi berada pada rentang hipertensi ringan (mild/grade 1). Begitu juga dengan penelitian Setiawan (2017) 
yang mendapatkan data lansia yang menderita hipertensi lebih banyak pada rentang derajat hipertensi ringan atau berada pada stadium 1 dengan rentang sistolik 140-159 $\mathrm{mmHg}$ dan diastolic 90-99 $\mathrm{mmHg}$ (Konita et al., 2015). Meskipun dalam rentang ringan, namun kondisi ini tetap merupakan keadaan hipertensi, mengingat komplikasi lanjutan akibat hipertensi yang tidak terkontrol. Hipertensi yang tidak terkontrol dengan baik dikhawatirkan akan menimbulkan komplikasi yang terkadang tidak disadari oleh penderita. Beberapa penelitian menunjukkan ada hubungan antara hipertensi dengan peningkatan terjadinya stroke (Yonata \& Satria, 2016).

Padahal berdasarkan American College of Cardiology/American Heart Association (ACC/AHA) (2017) mensyaratkan target tekanan darah normal pada lansia rentang usia > 65 tahun adalah $>130 \mathrm{mmHg}$ dan diastolic $>80 \mathrm{mmHg}$ bahkan The European Society of Cardiology/European Society of Hypertension (ESC/ESH) (2018) mensyaratkan target tekanan darah normal pada lansia adalah tekanan Sistolik direntang 130-139 mmHg dan diastolik pada rentang 70-79 mmHg (AHA/ACC, 2017; Agarwala, et al., 2020).

Berdasarkan hasil penelitian didapatkan kualitas tidur lansia dari 22 responden sebanyak 11 responden (50\%) memiliki kualitas tidur yang baik dan 11 orang responden $(50 \%)$ lainnya memiliki kualitas tidur yang buruk (Hanselidawati, 2012). Dari hasil ini diketahui jika kualitas tidur lansia termasuk dalam kategori yang buruk, meskipun secara jumlah seimbang. Kualitas tidur merupakan masalah yang kerap dialami lansia, bahkan menurut Ari et al., (2017) lebih dari separuh populasi lansia mengalami kualitas tidur yang buruk, hal ini tercatat dari hasil penelitian nya yang mendapatkan data sebanyak $19(63,3 \%)$ lansia dari 30 lansia di panti jompo tresna wana seraya Bali memiliki kualitas tidur yang buruk, penelitian lainnya melaporkan kualitas tidur yang tidak baik pada lansia di panti sosial tresna wherda Kota Jambi mencapai 24 responden $(66,7 \%)$ dari total 36 responden lansia (Ernawati et al., 2017). Berdasarkan penelitian sebelumnya ini, menunjukkan jika sebagian besar lansia mengalami masalah dengan kualitas tidur.

Lebih lanjut menurut Hidayat (2014) kualitas tidur meliputi aspek kuantitatif dan kualitatif tidur, seperti lamanya tidur, waktu yang diperlukan untuk tidur, frekuensi terbangun dan aspek subjektif seperti kedalaman dan kepulasan tidur.

Lansia yang tinggal dipanti sosial terkadang merasa kesepian baik karena ditinggalkan pasangan, jauh dari keluarga. Penelitian Wijayanti (2018) mendapatkan adanya hubungan level loneliness dengan kualitas tidur lansia yang tinggal di panti sosial. Kondisi ini juga menjadi salah satu aspek psikologis yang menyebabkan banyak lansia terutama yang tinggal di panti tresna wherda mengalami gangguan tidur yang berakibat pada buruknya kualitas tidur lansia. Pendapat peneliti pada penelitian ini juga sejalan dengan apa yang dikemukakan oleh Ari et al., (2017) yang mengemukakan adanya masalah pertemanan, keluarga dan lingkungan pada lansia yang menyebabkan mereka lebih banyak terjaga di malam hari, terlalu banyak memikirkan masalah tersebut yang membuat mereka sedih sendiri sehingga membutuhkan waktu yang lebih lama untuk tidur. Belum lagi dengan keluhan penyakit yang diderita seperti asam urat, rheumatoid artritis, kardiologi dan paru-paru.

\section{Analisis Bivariat}

Dari data hasil penelitian didapatkan ada hubungan yang signifikan dan erat antara kualitas tidur lansia dengan perubahan tekanan darah lansia hipertensi, ada pengaruh kualitas tidur terhadap perubahan tekanan darah lansia dengan hipertensi. 
Hasil penelitian ini sejalan dengan penelitian yang dilakukan oleh Yekti (2014); Sartika et al., (2020) yang menunjukkan ada hubungan kualitas tidur dengan tekanan darah pada lansia hipertensi, penelitian lainnya menunjukan jika kualitas tidur lansia mempengaruhi tekanan darah pada lansia dengan hipertensi seperti. Pada penelitian Setiawan et al., (2018) yang meneliti hubungan kualitas tidur dengan tekanan darah pada penderita hipertensi esensial di UPT rumah pelayanan sosial lanjut usia budi dharma Yogyakarta, didapatkan ada hubungan yang erat antara kualitas tidur dengan tekanan darah lanjut usia penderita.

Penelitian lainnya menunjukkan hasil yang sama seperti penelitian Refmaiza (2019) yang mendapatkan ada hubungan yang signifikan antara kualitas tidur dengan tekanan darah pada lansia riwayat hipertensi di puskesmas Andalas Kota Padang, yang berarti semakin tinggi nilai kualitas tidur dari kuisioner yang ada, maka semakin tinggi pula tekanan darah lansia hipertensi. Penelitian lain mengkonfirmasi hal yang sama, bahkan dengan adanya hipertensi mempengaruhi kualitas tidur lansia (Pradana, 2019). Peneliti pun dapat mengasumsikan jika semakin buruk kualitas tidur maka semakin rentan seseorang mengalami peningkatan tekanan darah, begitu juga sebaliknya.

Tidur merupakan aktivitas melibatkan berbagai sistem tubuh seperti saraf, endokrin, kardiovaskuler, respirasi, dan system musculoskeletal (Potter et al., 2016). Tidur mengubah fungsi saraf otonom dan peristiwa fisiologis lainnya yang mempengaruhi tekanan darah. Selama tidur normal terjadi penurunan tekanan darah relative selama terjaga. Penurunan ini disebabkan oleh saraf simpatik yang mengakibatkan terjadi penurunan 10-20\% dari tekanan darah normal selama terjaga. Sebaliknya jika setiap penurunan tekanan darah secara normal yang terjadi saat seseorang tidur tidak terjadi, maka kemungkinan 20\% akan meningkatkan tekanan darah, keadaaan ini terjadi akibat aktivasi sumbu hypothalamic-pituitary-adrenal dan system saraf simpatik yang terlihat pada penderita insomnia dan menyebaban kerentanan terhadap peningkatan tekanan darah /hipertensi.

Lebih lanjut hasil penelitian Writes (2017) menunjukkan jika orang dengan gangguan tidur dan durasi tidur pendek, didapati kemungkinan terbesar terjadi hipertensi sedikit lebih besar dua kali pada orang dengan tanpa masalah tersebut. Hubungan ini kemungkinan merupakan hasil dari mekanisme biologis, menunjukkan bahwa kurang tidur dapat mengubah hormon stress kortisol dan sistem saraf simpatik, sehingga terjadi peningkatan tekanan darah, ditambah apalagi memang seseorang itu mengalami stress dan kondisi kecemasan yang berlebih, misalnya akibat penyakit dan masalah yang dialami. Penelitian meta analysis yang dilakukan oleh Lo et al., (2018) menyimpulkan meskipun tidak secara signifikan ada hubungan antara kualitas tidur yang buruk dengan hipertensi, kualitas tidur yang buruk dan rendahnya jumlah waktu tidur mempengaruhi dan mengganggu irama sirkadian tubuh yang secara tidak langsung menjadi penyebab peningkatan resiko terjadinya hipertensi.

\section{SIMPULAN}

Berdasarkan hasil penelitian maka dapat diambil kesimpulan ada hubungan yang signifikan dan kuat antara kualitas tidur dengan perubahan tekanan darah pada lansia hipertensi di Panti Sosial Tresna Wherda Provinsi Bengkulu. Kualitas tidur yang buruk berpengaruh terhadap tekanan darah lansia dengan hipertensi. 


\section{SARAN}

Diharapkan lansia dapat rutin melakukan pengontrolan tekanan darah di klinik panti dan mencukupi kebutuhan tidur dengan menghindari hal-hal yang dapat menyebabkan gangguan tidur.

\section{DAFTAR PUSTAKA}

AHA / ACC. (2017). 2017 Guideline for the Prevention, Detection, Evaluation, and Management of High Blood Pressure in Adults a Report of the American College of Cardiology / American Heart Association T. In Journal of American College of Cardiology. https://doi.org/10.1161/HYP.0000000000000065/-/DC1

Alfie, J., \& Cuffaro, P. E. (2019). Hypertension in the Elderly. Encyclopedia of Biomedical Gerontology, 4(5), 258-270. https://doi.org/10.1016/B978-0-12801238-3.62166-9

Amanda, H., Prastiwi, S., \& Sutriningsih, A. (2016). Hubungan Kualitas Tidur dengan Tingkat Kekambuhan Hipertensi pada Lansia di Kelurahan Tlogomas Kota Malang Hafiez. Nursing News, 1, 358-368

Anandita, M. D., Mehta, A., Yang, E., \& Parapid, B. M. (2020). Older Adults and Hypertension: Beyond the 2017 Guideline for Prevention, Detection, Evaluation, and Management of High Blood Pressure in Adults. 26 Februari

Andri, J., Karmila, R., Padila, P., Harsismanto, J., \& Sartika, A. (2019). Pengaruh Terapi Aktivitas Senam Ergonomis terhadap Peningkatan Kemampuan Fungsional Lansia. Journal of Telenursing, 1(2), 304-313. https://doi.org/https://doi.org/10.31539/joting.v1i2.933

Andri, J., Waluyo, A., Jumaiyah, W., \& Nastashia, D. (2018). Efektivitas Isometric Handgrip Exercise dan Slow Deep Breathing Exercise terhadap Perubahan Tekanan Darah pada Penderita Hipertensi. Jurnal Keperawatan Silampari, 2(1), 371-384. https://doi.org/10.31539/jks.v2i1.382

Ari, V., Kumar, H., \& Ratep, N. (2017). Kualitas Tidur pada Geriatri di Panti Jompo Tresna Wana Seraya, Denpasar-Bali. Intisari Sains Media, 8(2), 151-154. https://doi.org/10.1556/ism.v8i2.132

Arif, D., \& Hartinah, D. (2013). Faktor-Faktor yang Berhubungan dengan Kejadian Hipertensi pada Lansia di Pusling Desa Klumpit UPT Puskesmas Gribig Kabupaten Kudus. JIKK, 4(2), 18-34

Babatsikou, F., \& Zavitsanou, A. (2010). Epidemiology of Hypertension in the Elderly. Health Science Journal, 4(1), 24-30

BPS. (2018). Statistik Penduduk Lansia 2017. Badan Pusat Statistik (BPS)

Dinkes Provinsi Bengkulu. (2019). Profil Kesehatan Provinsi Bengkulu 2018 Dinas Kesehatan Provinsi Bengkulu Tahun 2019. 211

Ernawati, S, A., \& Haisah, S. (2017). Gambaran Kualitas Tidur dan Gangguan Tidur Pada Lansia di Panti Sosial Tresna Werdha Budi Luhur Kota Jambi

Hanselidawati, H. (2012). Pola Tidur Lansia di Puskesmas Payolansek Kota Payakumbuh Sumatera Barat. Universitas Sumatera Utara

Heri, L. (2019). Info Demografi BKKBN. Demografi BKKBN, 1, 16

Hidayat, A. A. (2014). Pengantar Kebutuhan Dasar Manusia (2nd ed.). Jakarta: Salemba Medika

Iswahyuni, S. (2017). Hubungan antara Aktifitas Fisik dan Hipertensi pada Lansia. Profesi (Profesional Islam): Media Publikasi Penelitian, 14(2), 1. https://doi.org/10.26576/profesi.155 
Kemenkes RI. (2015). Rencana Strategis Kementerian Kesehatan Tahun 2015-2019. 1248

Kiik, S. M., Sahar, J., \& Permatasari, H. (2018). Peningkatan Kualitas Hidup Lanjut Usia (Lansia) di Kota Depok dengan Latihan Keseimbangan. Jurnal Keperawatan Indonesia, 21(2), 109-116. https://doi.org/10.7454/jki.v21i2.584

Konita, S., Azmi, S., \& Erkadius. (2015). Artikel Penelitian Pola Tekanan Darah pada Lansia di Posyandu Lansia Kelurahan Padang Pasir Padang Januari 2014. Jurnal Kesehatan Andalas, 4(1), 269-273

Lo, K., Woo, B., Wong, M., \& Tam, W. (2018). Subjective Sleep Quality, Blood Pressure, and Hypertension: A Meta-Analysis. Journal of Clinical Hypertension, 20(3), 592-605. https://doi.org/10.1111/jch.13220

Mahmudah, S., Maryusman, T., Arini, F. A., \& Malkan, I. (2015). Hubungan Gaya Hidup dan Pola Makan dengan Kejadian Hipertensi pada Lansia Di Kelurahan Sawangan Baru Kota Depok Tahun 2015. Biomedika, 7(2), 43-51. https://doi.org/10.23917/biomedika.v7i2.1899

Martini, S., Roshifanni, S., \& Marzela, F. (2018). Pola Tidur yang Buruk Meningkatkan Risiko Hipertensi. Media Kesehatan Masyarakat Indonesia, 14(3), 297. https://doi.org/10.30597/mkmi.v14i3.4181

Mubarak, W. I., Indrawati, L., \& Susanto, J. (2015). Buku Ajar Ilmu Keperawatan Dasar. Jakarta: Salemba Medika

Nuraini, B. (2015). Risk Factors of Hypertension. J Majority, 4(5), 10-19

Ode, S. L. (2012). Asuhan Keperawatan Gerontik. Yogyakarta: Nuha Medika

P2PTM Kemenkes RI. (2019). Hari Hipertensi Dunia 2019: "Know Your Number, Kendalikan Tekanan Darahmu dengan CERDIK."

Padila, P. (2012). Buku Ajar Keperawatan Medikal Bedah. Yogyakarta: Nuha Medika

Padila, P. (2013). Buku Ajar Keperawatan Gerontik. Yogyakarta: Nuha Medika

Potter, P. A., Perry, A. G., Stockert, P., \& Hall, A. (2016). Fundamental of Nursing (9th ed.). Elsevier

Pradana, S. S. (2019). Hubungan Tekanan Darah Tinggi dengan Kualitas Tidur pada Lansia di Posyandu Lansia Pandanwangi Blimbing Kota Malang. Universitas Muhammadiyah Malang

Primahadi, O. (2017). Promosi Kesehatan Jadi Pilar Utama Pembangunan Kesehatan

Pusat Data dan Informasi Kemenkes RI. (2014). Pusdatin Hipertensi. Infodatin, Hipertensi, 1-7. https://doi.org/10.1177/109019817400200403

Refmaiza, F. (2019). Hubungan Kualitas Tidur dengan Tekanan Darah pada Lansia Riwayat Hipertensi di Puskesmas Andalas Kota Padang [Universitas Andalas]. https://doi.org/.1037//0033-2909.I26.1.78

Ridwan, R., Widodo, D., \& Widiani, E. (2017). Hubungan Hipertensi dengan Kecemasan pada Lanjut Usia di Posyandu Permadi Kelurahan Tlogomas Kecamatan Lowokwaru Kota Malang. Nursing News, 2(3), 676-686

Riskesdas Kementerian Kesehatan RI. (2018). Hasil Utama Riset Kesehatan Dasar (RISKESDAS) (Vol. 44, Issue 8). https://doi.org/10.1088/1751-8113/44/8/085201

Sartika, A., Betrianita, B., Andri, J., Padila, P., \& Nugrah, A. V. (2020). Senam Lansia Menurunkan Tekanan Darah pada Lansia. Journal of Telenursing, 2(1), 11-20. https://doi.org/https://doi.org/10.31539/joting.v2i1.1126 
Sartika, A., Wardi, A., \& Sofiani, Y. (2018). Perbedaan Efektivitas Progressive Muscle Relaxation (PMR) dengan Slow Deep Breathing Exercise (SDBE) terhadap Tekanan Darah Penderita Hipertensi. Jurnal Keperawatan Silampari, 2(1), 356370. https://doi.org/https://doi.org/10.31539/jks.v2i1.380

Setiawan, A. B. (2017). Hubungan antara Tingkat Stres dan Kecemasan dengan Kejadian Hipertensi pada Lansia di Klinik Islamic Center Samarinda. Jurnal Ilmu Kesehatan, 5(1), 67-75

Setiawan, A., Maulana, D., \& Widyaningrum, R. (2018). Hubungan Kualitas Tidur Dengan Tekanan Darah Lanjut Usia Penderita Hipertensi Esensial di UPT Rumah Pelayanan Sosial Lanjut Usia Budi Dharma Yogyakarta. Jurnal Kesehatan Madani Medika, 9(1), 55-63. https://doi.org/10.36569/jmm.v9i1.21

Sudarso, S., Kusbaryanto, K., Khoiriyati, A., \& Huriah, T. (2019). Efektivitas Pemberian Intervensi Gerakan Sholat terhadap Penurunan Tekanan Darah pada Lansia dengan Hipertensi. Jurnal Keperawatan, 12(1), 76-86

Whelton, P. K., Carey, R. M., Aronow, W. S., Casey, D. E., Collins, K. J., Himmelfarb, C. D., DePalma, S. M., Gidding, S., Jamerson, K. A., Jones, D. W., MacLaughlin, E. J., Muntner, P., Ovbiagele, B., Smith, S. C., Spencer, C. C., Stafford, R. S., Taler, S. J., Thomas, R. J., Williams, K. A., \& Hundley, J. (2018). 2017 ACC/AHA/AAPA/ABC/ACPM/AGS/APhA/ASH/ASPC/NMA/PCNA Guideline for the Prevention, Detection, Evaluation, and Management of High Blood Pressure in Adults a Report of the American College of Cardiology/American Heart Association Task Force on Clinical pr. In Hypertension (Vol. 71, Issue 6). https://doi.org/10.1161/HYP.0000000000000065

Wijayanti, W. (2018). Hubungan Loneliness Level dengan Kualitas Tidur Lansia di Panti Sosial Tresna Wherda Unit Abiyoso Pakem Sleman. Universitas Aisyiyha Yogyakarta

Writes, S. (2017). Common Causes of Hypertension in Senior Adults. Health Science Journal, 11(4), 1000523. https://doi.org/10.21767/1791-809x.1000523

Yekti, S. (2014). Hubungan Kualitas Tidur dengan Tekanan Darah pada Lansia Hipertensi di Gamping Sleman Yogyakarta. Naskah Publikasi

Yonata, A., \& Satria, A. P. P. (2016). Hipertensi sebagai Faktor Pencetus Terjadinya Stroke. Majority, 5(2), 17

Zulfitri, Z., Reni, A., \& Agrina, A. (2018). Hubungan Kondisi Psikososial Lansia Hipertensi dengan Kejadian Insomnia. JOM FKp, 5(2), 51-61 